\title{
DETERMINAN TARIF PAJAK EFEKTIF PADA PERUSAHAAN YANG TERDAFTAR DI BURSA EFEK INDONESIA
}

\author{
Kennardi Tanujaya* dan Ivo Valentine* \\ *Program Studi Akuntansi, Fakultas Ekonomi \\ Universitas Internasional Batam \\ Email: kennardi.tanujaya@uib.ac.id; ivovalentine29@gmail.com
}

\begin{abstract}
The purpose of this study is to analyze the determinants of effective tax rates. Independent variables in research are company size, audit committee, leverage, independent commissioners, inventory intensity, return on asset, audit quality, capital intensity, and institutional ownership. GAAP ETR and Current ETR are the dependent variables in this research.

493 companies listed on the Indonesia Stock Exchange from 2014 to 2018 act as the study population. Sample selection is done using a purposive sampling technique. 216 companies that fulfilled certain criteria are included as samples for the study.

Test results conclude that the rate of return on assets and firm size had a significant negative effect, while institutional ownership had a significant positive effect on the two dependent variables, namely GAAP ETR and Current ETR. Leverage has a significant positive effect on GAAP ETR but has no significant effect on Current ETR. Other independent variables, namely audit quality, inventory intensity, audit committee, capital intensity, and independent commissioners do not show any significant effect on GAAP ETR and Current ETR.
\end{abstract}

Keywords: ETR, audit quality, corporate governance, firm characteristics

\section{PENDAHULUAN}

Menurut Prasetyo, Masitoh, dan Wijayanti (2018), pajak adalah kontribusi berupa uang yang terutang oleh rakyat selaku subjek pajak (badan usaha atau pribadi) kepada negara yang sifatnya memaksa dan diatur oleh undang-undang dan imbalan tidak diperoleh secara langsung. Sebagai sumber pemasukan perekonomian negara, pemerintah mengharapkan partisipasi membayar pajak oleh wajib pajak yang hasilnya akan dilakukan perencanaan pembangunan untuk dinikmati masyarakat. Dengan demikian, wajib pajak diharapkan untuk mematuhi kewajiban dan regulasi perpajakan secara sukarela dan sepenuh hati (Yustrianthe \& Niandari, 2018).

Menurut Zulaikha (2014), pajak adalah biaya bagi sebuah perusahaan yang mampu mengurangi laba perusahaan, yang dimana mayoritas perusahaan membayar pajak secara tidak sukarela. Selain itu, manfaat yang diperoleh dari membayar pajak tidak dapat dirasakan oleh perusahaan secara langsung. Hal ini mendorong manajemen perusahaan untuk berusaha meminimalisasi biaya pajak supaya meningkatkan pendapatan perusahaan melalui perencanaan pajak (Putri, 2016).

Sistem pemungutan banyak perubahan dari awal kemerdekaan hingga sekarang. Sistem pemungutan pajak yang diterapkan dari tahun 1983 hingga sekarang merupakan self-assessment system. Menurut Mappadang, Widyastuti, dan Wijaya (2018), sistem ini dapat diterapkan secara baik apabila terdapat tingginya kepatuhan pajak dan sukarela di komunitas.

Reformasi mengenai pajak penghasilan terakhir diatur pada UU Nomor 36 Tahun 2008. Perubahan yang dikategorikan signifikan salah satu diantaranya adalah perubahan pajak perseroan yang dahulunya menggunakan tarif progresif menjadi tarif tunggal (Savitri \& Andreas, 2017). Penerapan tarif progresif 
yang dimana biaya pajak meningkat seiring dengan pendapatan menjadi tarif tunggal, yaitu $25 \%$. Penyederhanaan serta pengurangan dalam perhitungan pajak diharapkan dapat meningkatkan perekonomian dan investasi di Indonesia. Di sisi lain, perusahaan ingin melakukan penghindaran pajak dengan tidak membayar pajak sesuai dengan tarif yang ditetapkan.

Penghindaran pajak ialah langkahlangkah yang diambil secara legal untuk menghindar pajak oleh wajib pajak (Marselawati, Titisari, \& Masitoh, 2018). Menurut Mahulae, Pratomo, dan Nurbaiti (2016), alasan mengapa wajib pajak menerapkan penghindaran pajak ialah penghasilan utama perusahaan ditujukan untuk memuaskan kebutuhan pribadi yang menyebabkan pertentangan antara kepentingan negara dan pribadi.

Tandean dan Winnie (2016) dan Waluyo (2017) pada penelitiannya menggunakan ETR sebagai proksi dalam menghitung tingkat penghindaran pajak. Dengan demikian, ETR dijadikan sebagai tolak ukur penghindaran pajak. Nilai ETR sebuah perusahaan sering dimanfaatkan oleh instansi pemerintah serta pihak yang berkepentingan sebagai metode untuk melakukan pengamatan terhadap sistem pajak badan usaha karena menghasilkan deskripsi statistika yang mudah atas pengaruh gabungan berbagai jenis insentif pajak berserta selisih tarif pajak penghasilan sebuah perusahaan (Gupta \& Newberry, 1997).

Penghindaran pajak suatu perusahaan dapat dijelaskan dengan ETR. Perbedaan pendapat tingkat pengaruh karakteristik perusahaan, tata kelola perusahaan, dan kualitas audit terhadap ETR mendorong peneliti untuk melakukan penelitian terhadap determinan ETR di Indonesia, dengan judul penelitian "Determinan Tarif Pajak Efektif pada Perusahaan Terbuka yang Terdaftar di Bursa Efek Indonesia".

\section{KAJIAN LITERATUR PENGEMBANGAN HIPOTESIS}

DAN

\subsection{Effective Tax Rate}

ETR atau adalah Effective Tax Rate variabel dependen yang dipilih dalam topik penelitian ini. ETR merupakan persentase pajak yang menjadi tanggungan sebuah perusahaan dengan membandingkan persentase jumlah beban pajak tanggungan terhadap laba perusahaan dalam periode tertentu. ETR diartikan sebagai beban pajak penghasilan yang dibagi dengan pendapatan perusahaan sebelum pajak (Richardson \& Lanis, 2007). Pengukuran ETR merupakan pengukuran beban pajak karena menandakan tingkat biaya pajak yang dibayar perusahaan terhadap penghasilan suatu periode (Noor, Fadzillah, \& Mastuki, 2010).

$$
\text { Stickney dan Mcgee }
$$

mendefinisikan ETR sebagai semua pendapatan yang terutang pajak dibagi dengan pendapatan sebelum pajak sebelum pajak disesuaikan untuk efek perbedaan waktu. ETR adalah proksi mengukur manajemen pajak yang merupakan strategi pengurangan pajak, sehingga perusahaan memperoleh laba setelah pajak yang lebih tinggi (Jasrial, Puspitasari, \& Muktiyanto, 2018). Tinggi rendahnya ETR setiap perusahaan berbeda-beda, tergantung efektivitas pengelolaan manajemen dalam memanfaatkan aktivitas-aktivitas yang dapat menurunkan laba perusahaan.

Pajak penghasilan di Indonesia mengalami perubahan, perubahan terakhir di atur pada UU Nomor 36 Tahun 2008. Perubahan ini tetap memegang prinsip perpajakan secara universal, yakni efisiensi administrasi, kemudahan, keadilan, dan peningkatan serta optimalisasi dan peningkatan penerimaan negara melalui sistem self assessment. Menaikkan daya saing dan menarik investasi di Indonesia merupakan bagian dari tujuan penyempurnaan undang-undang, dimana salah satu perubahan signifikan ialah tarif pajak penghasilan badan menjadi $25 \%$.

Pendapatan di laporan laba rugi tidak mencerminkan pendapatan yang dihitung dalam perpajakan. Hal ini disebabkan oleh 
perbedaan pengakuan antara prinsip akuntansi dan perpajakan. Salah satu contohnya adalah masa manfaat aset tetap yang menyebabkan perbedaan pengakuan biaya depresiasi. Penelitian ini menggunakan laba sebelum pajak (earning before tax) sebagai penyebut dalam mengukur ETR. Menurut Kraft (2014), biaya bunga adalah komponen pengurang pajak, sehingga menggunakan laba sebelum bunga dan pajak tidak merupakan pengukuran yang tepat.

Terdapat beberapa beban pajak yang digunakan dalam menghitung ETR. Gupta dan Newberry (1997) dan Rego (2003) menggunakan beban pajak kini dalam mengukur ETR. Menurut Kraft (2014), menghilangkan pajak tangguhan bisa menghasilkan beban pajak menjadi bias secara keseluruhan, sehingga menggunakan jumlah beban pajak hasilnya lebih akurat.

\subsection{Variabel Independen terhadap Dependen}

\subsubsection{Ukuran Perusahaan terhadap ETR}

Ukuran merupakan skala sebuah perusahaan yang dicerminkan oleh jumlah aset yang dimiliki perusahaan (Rani, Susetyo, \& Fuadah, 2018). Menurut political cost theory, teori tersebut berasumsi bahwa perusahaan yang ukurannya semakin besar, maka ETR yang dibayar semakin besar karena kecenderungan untuk dijadikan sasaran atau fokus perhatian lebih dari publik dan pemerintah sehingga mempersulit pihak manajemen dalam melakukan penghematan pajak (Zimmerman, 1983).

Hasil penelitian penelitian Parisi (2016) dan Noor et al. (2010) mendukung teori political cost theory dimana ukuran perusahaan memiliki hubungan signifikan positif terhadap ETR. Penyebabnya adalah transparansi dan lebih ketatnya pemantauan oleh publik dan pemerintah terhadap perusahaan besar.

$\mathrm{H}_{1}$ :

a. Ukuran perusahaan berpengaruh signifikan positif terhadap GAAP ETR.

b. Ukuran perusahaan berpengaruh signifikan positif terhadap Current ETR.

\subsubsection{Leverage terhadap ETR}

Menurut Astuti, Titisari, dan Nurlaela (2018), rasio leverage merupakan tingkat kemampuan tertentu perusahaan dalam menggunakan pendanaan melalui utang. Pendanaan melalui utang merupakan keuntungan bagi perusahaan karena bunga yang dibayar dikategorikan sebagai pengurang pajak (Koh \& Lee, 2015). Tingginya biaya bunga akan menurunkan penghasilan perusahaan, dan semakin kecil beban pajak perusahaan (Wiratmoko, 2018). Hasil penelitian Inua (2018), Zeng (2014) dan Noor et al. (2010) juga menunjukkan pengaruh signifikan negatif terhadap ETR.

$\mathrm{H}_{2}$ :

a. Leverage berpengaruh signifikan negatif terhadap GAAP ETR.

b. Leverage berpengaruh signifikan negatif terhadap Current ETR.

\subsubsection{Intensitas Modal terhadap ETR}

Besaran aset perusahaan yang diinvestasikan pada aset tetap merupakan intensitas modal (Sonia \& Suparmun, 2019). Aset tetap memiliki masa manfaat atau pemakaian di atas satu tahun yang dimiliki oleh perusahaan. Menurut Ogbeide (2017), perusahaan yang menanamkan investasi yang besar di aset fisik cenderung memanfaatkan biaya depresiasi dalam perencanaan pajak dengan mengurangi pendapatan kena pajak dan pajak yang dibayar. Pengaruh bersignifikan negatif terhadap ETR terbukti dari hasil penelitian Noor et al. (2010), Ogbeide (2017), dan Parisi (2016) karena perusahaan mengelola dan memanfaatkan biaya penyusutan aset tetap sebagai pengurang pendapatan yang berujung pada penurunan biaya pajak.

$\mathrm{H}_{3}$ :

a. Intensitas modal berpengaruh signifikan negatif terhadap GAAP ETR.

b. Intensitas modal berpengaruh signifikan negatif terhadap Current ETR.

\subsubsection{Intensitas Persediaan terhadap ETR}

Intensitas persediaan menjelaskan proprorsi persediaan yang dimiliki terhadap 
jumlah aset badan (Sonia \& Suparmun, 2019). Intensitas persediaan harus dipertimbangkan ketika memperhitungkan komposisi aset. Hal ini berarti investasi persediaan bisa di anggap alternatif pada investasi aset tidak lancar yang mengurangi kemungkinan memperoleh ETR yang lebih rendah (Parisi, 2016). Gupta dan Newberry (1997) pada penelitiannya menyajikan bahwa perusahaan di sektor manufaktur memiliki nilai ETR yang lebih rendah dibandingkan perusahaan grosir dan eceran.

Noor et al. (2010), Jasrial et al. (2018), serta Rodríguez dan Arias (2014) pada hasil penelitiannya menunjukkan pengaruh signifikan positif terhadap ETR. Persediaan barang dagang adalah aset yang tidak dapat mengurangi pajak, berbeda dengan aset tetap yang bisa memanfaatkan biaya depresiasi sebagai pengurang pajak.

$\mathrm{H}_{4}$ :

a. Intensitas persediaan berpengaruh signifikan positif terhadap GAAP ETR.

b. Intensitas persediaan berpengaruh signifikan positif terhadap Current ETR.

\subsubsection{Pengaruh Tingkat Pengembalian Aset terhadap ETR}

Tingkat pengembalian aset menunjukkan tingkat profitabilitas sebuah perusahaan. Rego (2003) menilai bahwa profitabilitas perusahaan yang tinggi menghasilkan biaya pajak yang cenderung rendah sebab mereka memiliki sumber untuk berinvestasi di kegiatan perencanaan pajak. Hasil penelitian Wiratmoko (2018), Noor et al. (2010), dan Parisi (2016) juga membuktikan pengaruh signifikan negatif terhadap ETR karena semakin besar pendapatan, maka manajemen akan semakin efisien dalam melakukan perencanaan pajak dalam mengurangi ETR.

$\mathrm{H}_{5}$ :

a. Tingkat pengembalian aset berpengaruh signifikan negatif terhadap GAAP ETR.

b. Tingkat pengembalian aset berpengaruh signifikan negatif terhadap Current ETR.

\subsubsection{Komite Audit terhadap ETR}

Komite audit adalah aspek penting ketika mengimplementasi tata kelola perusahaan yang bertujuan memantau perusahaan bersama dewan komisaris (Arismajayanti \& Jati, 2017). Menurut Widuri et al. (2019), minimnya jumlah anggota komite audit akan meningkatkan kemungkinan manajemen yang akan melakukan penghindaran pajak, begitu pula sebaliknya. Penelitian Dina et al. (2018), Widuri et al. (2019) dan Zulaikha (2013) menunjukkan hasil yang sama, dimana komite audit memantau manajemen perusahaan dan memiliki pengetahuan dibidang akuntansi untuk menghindari praktik penghindaran pajak.

$\mathrm{H}_{6}$ :

a. Komite audit berpengaruh signifikan positif terhadap GAAP ETR.

b. Komite audit berpengaruh signifikan positif terhadap Current ETR.

\subsubsection{Pengaruh Kepemilikan Institusional terhadap ETR}

Kepemilikan institusional memegang peranan dalam memantau berbagai kebijakan yang dibuat oleh manajer dalam pengambilan keputusan untuk menghasilkan efektivitas pada perusahaan (Nugroho \& Agustia, 2017). Ketika institusi memiliki saham yang lebih banyak daripada pemegang saham lain, fungsi pemantauan pada manajemen lebih efektif karena membuat manajemen lebih waspada ketika mengambil keputusan seperti kebijakan perusahaan terkait meminimalisasi pajak (Sonia \& Suparmun, 2019). Hal ini dikarenakan perusahaan institusional memiliki modal kuat, pengetahuan, dan lebih berpengalaman dibanding kepemilikan individu (Mappadang et al., 2018). Hasil penelitian Wahab, Ariff, Marzuki, dan Sanusi (2017), Mappadang et al. (2018), serta Sonia dan Suparmun (2019), serta juga menunjukkan pengaruh signifikan positif terhadap ETR.

$\mathrm{H}_{7}$ :

a. Kepemilikan institusional berpengaruh signifikan positif terhadap GAAP ETR. 
b. Kepemilikan institusional berpengaruh signifikan positif terhadap Current ETR.

\subsubsection{Komisaris Independen terhadap ETR}

Komisaris independen adalah orang yang bebas, tidak di bawah tekanan pihak manapun, netral, objektif, serta tidak berada didalam posisi konflik kepentingan (Murni, Sudarmaji, \& Sugihyanti, 2016). Kehadiran komisaris independen bertindak sebagai pihak yang objektif dan independen dalam menyediakan kesetaraan antara berbagai pihak, terutama pemegang saham minoritas atau mayoritas dengan stakeholders, misalnya debitor, manajer, kreditor, atau pihak lain yang berkaitan dengan kepentingan perusahaan (Nugroho \& Agustia, 2017).

Hasil penelitian Zulaikha (2014), Prasetyo et al. (2018), dan Widuri et al. (2019) juga menunjukkan pengaruh signifikan positif terhadap ETR.

$\mathrm{H}_{8}$ :

a. Komisaris independen berpengaruh signifikan positif terhadap GAAP ETR.

b. Komisaris independen berpengaruh signifikan positif terhadap Current ETR.

\subsubsection{Kualitas Audit terhadap ETR}

Perusahaan audit Big 4 disebut sebagai 4 perusahaan audit terbesar di dunia. 4 perusahaan audit tersebut terdiri dari Deloitte, $P w C, E Y$, dan KPMG. Laporan keuangan yang diaudit oleh KAP seperti Big 4 mempunyai kualitas tertentu sebab auditor KAP Big 4 dilatih dengan baik dan mengerti prosedur berkaitan serta program audit mereka lebih akurat dan efektif dibanding KAP lain (Waluyo, 2017).

Hasil penelitian Kurniasih et al. (2017), dan Widuri et al. (2019) menunjukkan bahwa kualitas audit berpengaruh signifikan positif terhadap ETR karena kualitas audit termasuk salah satu struktur tata kelola yang paling efektif karena melindungi pengguna dari aksi kemungkinan kecurangan yang dilakukan manajemen. $\mathrm{H}_{9}$ a. Kualitas audit berpengaruh signifikan positif terhadap GAAP ETR.

b. Kualitas audit berpengaruh signifikan positif terhadap Current ETR.

\section{METODE PENELITIAN}

Suatu kesatuan, meliputi rencana terperinci dan spesifik dalam hal cara memperoleh, menganalisis dan mengolah data disebut rancangan penelitian (Timotius, 2017). Model yang diteliti termasuk ke dalam penelitian kuantitatif. Salah satu ciri data kuantitatif adalah numerik, menggunakan angka, tidak deskriptif, memanfaatkan statistika atau matematika. Penelitian historis dipakai pada penelitian ini, dimana data objek penelitian berasal dari data-data entitas yang telah terjadi sebelumnya (Sugiyono, 2017). Menurut Indriantoro dan Supomo (2014), kausal komparatif menganalisa hubungan sebab akibat di antara 2 variabel atau lebih.

Data yang tercantum pada laporan keuangan perusahaan dalam daftar BEI dari tahun 2014-2018 dijadikan sebagai objek dalam melakukan penelitian. Pemilihan data sampel sesuai dengan kriteria dalam topik penelitian. Purposive sampling ialah berbagai kriteria digunakan ketika mengambil sampel (Sugiyono, 2017). Kriteria atau syarat yang ditetapkan dalam mengambil sampel di penelitian ini, yaitu:

1. Perusahaan terbuka yang masuk dalam daftar BEI selama periode 2014-2018.

2. Laporan berupa laporan keuangan perusahaan yang memiliki data untuk mengukur variabel independen.

3. Perusahaan yang dijadikan sampel tidak terjadi delisting pada waktu pengamatan data.

4. Perusahaan yang dijadikan sampel memiliki laba sebelum pajak (earning before $\operatorname{tax}$ ) positif. Kriteria ini digunakan karena pajak penghasilan dikenakan atas laba yang diperoleh, sehingga perusahaan bukan merupakan subjek pajak penghasilan ketika mengalami kerugian (Maskanah \& Islahuddin, 2019). 
5. Nilai ETR dari sampel perusahaan adalah antara $0 \%$ dan $100 \%$ (tidak bernilai negatif dan $>0$ ). Kriteria ini juga diterapkan pada penelitian Salaudeen dan Akano (2018), Noor et al. (2010), dan Zheng et al. (2019) karena diluar nilai tersebut akan menyebabkan distorsi atau penyimpangan pada hasil penelitian.

\subsection{GAAP ETR}

Tarif pajak GAAP diartikan sebagai rasio jumlah beban pajak pada pendapatan sebelum pajak sebuah perusahaan (Khaoula \& Ali, 2012). Skala pengukuran GAAP ETR adalah skala rasio. Pengukuran ETR pada penelitian sejalan dengan Kraft (2014) yang menggunakan jumlah beban pajak sebagai pembilang karena akan menghasilkan nilai yang lebih akurat.

$$
\text { GAAP ETR }=\frac{\text { Jumlah Beban Pajak }}{\text { Pendapatan Sebelum Pajak }}
$$

\subsection{Current ETR}

Current ETR merupakan rasio beban pajak kini pada pendapatan perusahaan sebelum pajak (Sonia \& Suparmun, 2019). Skala pengukuran Current ETR adalah skala rasio. Pengukuran ETR pada penelitian sejalan dengan Tandean dan Winnie (2016), dimana beban pajak kini dijadikan pembilang. Jumlah Pajak Kini

$$
\text { Current ETR }=\overline{\text { Pendapatan Sebelum Pajak }}
$$

\subsection{Ukuran Perusahaan}

Menurut Wiratmoko (2018), sebuah skala atau nilai untuk menunjukkan besar kecilnya sebuah perusahaan, antara lain berdasarkan jumlah aset, log size, dan banyak lagi disebut ukuran perusahaan. Skala rasio ialah skala pengukuran variabel ukuran perusahaan. Penelitian ini mengadopsi Pratama (2017) yang mengukur variabel sebagai berikut:

Ukuran Perusahaan = Logaritma Natural Total Aset

\subsection{Leverage}

Leverage adalah kemampuan perusahaan dalam menggunakan utang sebagai investasi pendanaan (Yustrianthe \& Niandari, 2018). Skala rasio ialah skala pengukuran variabel leverage. Penelitian ini mengadopsi Salaudeen dan Akano (2018) yang mengukur variabel sebagai berikut:

\subsection{Intensitas Modal}

Intensitas modal menunjukkan komposisi aset yang berpengaruh terhadap ETR, yaitu aset tetap akan mengurangi beban pajak dari penyusutan setiap tahun (Delgado, Rodriguez, \& Arias, 2012). Skala rasio ialah skala pengukuran variabel intensitas modal. Penelitian ini mengadopsi Savitri dan Andreas (2017) yang mengukur variabel intensitas modal sebagai berikut:

$$
\text { Intensitas Modal }=\frac{\text { Jumlah Aset Tetap }}{\text { Jumlah Aset }}
$$

\subsection{Intensitas Persediaan}

Intensitas persediaan merupakan proporsi jumlah persediaan pada jumlah aset (Salaudeen \& Akano, 2018). Skala rasio ialah skala pengukuran variabel intensitas persediaan. Penelitian ini mengadopsi Savitri dan Andreas (2017) yang mengukur variabel intensitas persediaan sebagai berikut:

$$
\text { Intensitas Persediaan }=\frac{\text { Persediaan }}{\text { Jumlah Aset }}
$$

\subsection{Tingkat Pengembalian Aset}

Rasio profitabilitas yang mendeskripsikan kapabilitas perusahaan untuk menghasilkan pendapatan melalui efisiensi penggunaan aset disebut tingkat pengembalian aset (Wiratmoko, 2018). Skala rasio ialah skala pengukuran variabel tingkat pengembalian aset. Penelitian ini mengadopsi Khaoula dan Ali (2012) yang mengukur variabel sebagai berikut:

$$
\begin{aligned}
& \text { Tingkat } \\
& \text { Pengembalian Aset }
\end{aligned}=\frac{\text { Laba Sebelum Pajak }}{\text { Jumlah Aset }}
$$




\subsection{Komite Audit}

Bapepam-LK mengartikan komite audit sebagai pihak yang dibentuk oleh dan bertugas kepada dewan komisaris untuk membantu dalam menjalankan fungsi dan tugasnya. Skala rasio ialah skala pengukuran variabel komite audit. Penelitian ini mengadopsi Widuri et al (2019) yang mengukur variabel komite audit sebagai berikut:

Komite Audit = Jumlah Komite Audit

\subsection{Kepemilikan Institusional}

Kepemilikan institusional merupakan investor institusional yang menguasai saham perusahaan dalam bentuk persentase, termasuk perusahaan dana pensiun, asuransi, bank investasi, dan sejenisnya (Murni et al., 2016). Skala rasio ialah skala pengukuran variabel kepemilikan institusional. Penelitian ini mengadopsi Tandean dan Winnie (2016) yang mengukur variabel sebagai berikut

$\underset{\text { Institusional }}{\text { Kepemilikan }}=\frac{\text { Jumlah Saham Institusional }}{\text { Jumlah Saham }}$

\subsection{Komisaris Independen}

Menurut Bapepam-LK, komisaris independen diartikan sebagai anggota dewan komisaris eksternal, dimana saham secara langsung dan tidak langsung perusahaan tidak dimiliki, dan tidak adanya relasi atau pihak berkepentingan dengan perusahaan, serta tidak terdapat koneksi usaha secara langsung dan tidak langsung dengan perusahaan. Skala rasio ialah skala pengukuran variabel komisaris independen. Kurniasih et al. (2017) menggunakan cara ini untuk mengukur variabel:

$\begin{aligned} & \text { Komisaris } \\ & \text { Independen }\end{aligned}=\frac{\text { Jumlah Komisaris Independen }}{\text { Jumlah Komisaris }}$

\subsection{Kualitas Audit}

Semua probabilitas yang mungkin terjadi ketika auditor memeriksa laporan keuangan audit dan mencari pelanggaran $0=$ perusahaan audit non Big 4 . serta melaporkannya dalam laporan keuangan yang sudah diaudit disebut kualitas audit (Yustrianthe \& Niandari, 2018). Skala nominal ialah skala pengukuran variabel kualitas audit. Penelitian ini mengadopsi Wahab et al. (2015) yang mengukur variabel sebagai berikut:

Kualitas Audit:

1= perusahaan audit Big 4 .

\section{HASIL PENELITIAN}

\subsection{Statistik Deskriptif}

493 perusahaan yang terdaftar di BEI dari tahun 2014 - 2018 merupakan sampel yang diteliti, namun perusahaan yang memenuhi kriteria berjumlah 216 perusahaan. Software SPSS versi 22 digunakan untuk mengolah data yang diuji. Jumlah sampel yang memenuhi kriteria dan setelah outlier untuk GAAP ETR dan Current ETR masing-masing adalah 1.033 dan 1.030 data.

Tabel 1

Rangkuman Pemilihan Sampel dan Data Penelitian

\begin{tabular}{|l|c|c|}
\hline Keterangan & $\begin{array}{c}\text { GAAP } \\
\text { ETR }\end{array}$ & $\begin{array}{c}\text { Current } \\
\text { ETR }\end{array}$ \\
\hline Perusahaan yang terdaftar di BEI & 493 & 493 \\
\hline $\begin{array}{l}\text { Perusahaan yang tidak } \\
\text { memenuhi kriteria }\end{array}$ & 277 & 277 \\
\hline $\begin{array}{l}\text { Perusahaan yang dijadikan } \\
\text { sampel }\end{array}$ & 216 & 216 \\
\hline Tahun penelitian & 5 & 5 \\
\hline Jumlah data penelitian & 1.080 & 1.080 \\
\hline Jumlah data outlier & 47 & 50 \\
\hline Jumlah data sampel & 1.033 & 1.030 \\
\hline
\end{tabular}

Sumber: Data sekunder diolah (2019) 
Tabel 2

Hasil Uji Statistik Deskriptif Variabel Penelitian GAAP ETR

\begin{tabular}{|l|c|c|c|c|}
\hline Variabel & Minimum & Maksimum & Rata-Rata & Standar Deviasi \\
\hline GAAP ETR & 0,00043 & 0,58816 & 0,23464 & 0,09961 \\
\hline $\begin{array}{l}\text { Ukuran Perusahaan (dalam } \\
\text { miliar rupiah) }\end{array}$ & 46,76093 & $1.296 .898,29200$ & $35.633,67150$ & $124.561,60843$ \\
\hline Leverage & 0,05230 & 0,95334 & 0,50208 & 0,22088 \\
\hline Intensitas Modal & 0,00025 & 0,90621 & 0,23526 & 0,21507 \\
\hline Intensitas Persediaan & 0,00000 & 0,72865 & 0,14279 & 0,15441 \\
\hline Tingkat Pengembalian Aset & 0,00072 & 0,70915 & 0,08976 & 0,09203 \\
\hline Komite Audit & 1 & 7 & 3,20523 & 0,63832 \\
\hline Kepemilikan Institusional & 0 & 0,99999 & 0,23566 & 0,30952 \\
\hline Komisaris Independen & 0,16667 & 0,83333 & 0,42585 & 0,11641 \\
\hline
\end{tabular}

Sumber: Data sekunder diolah (2019)

Tabel 3

Hasil Uji Statistik Deskriptif Variabel Penelitian Current ETR

\begin{tabular}{|l|c|c|c|c|}
\hline Variabel & Minimum & Maksimum & Rata-Rata & Standar Deviasi \\
\hline Current ETR & 0,00071 & 0,60898 & 0,23692 & 0,10881 \\
\hline $\begin{array}{l}\text { Ukuran Perusahaan } \\
\text { (dalam miliar rupiah) }\end{array}$ & 46,76093 & $1.296 .898,29200$ & $35.641,45092$ & $124.734,93978$ \\
\hline Leverage & 0,05230 & 0,95334 & 0,50269 & 0,22039 \\
\hline Intensitas Modal & 0,00025 & 0,87750 & 0,23630 & 0,21587 \\
\hline Intensitas Persediaan & 0,00000 & 0,72865 & 0,14225 & 0,15389 \\
\hline Tingkat Pengembalian Aset & 0,00051 & 0,70915 & 0,09033 & 0,09192 \\
\hline Komite Audit & 1 & 7 & 3,21 & 0,647 \\
\hline Kepemilikan Institusional & 0 & 0,99999 & 0,23601 & 0,30969 \\
\hline Komisaris Independen & 0,16667 & 0,83333 & 0,42509 & 0,11625 \\
\hline
\end{tabular}

Sumber: Data sekunder diolah (2019)

Tabel 4

Hasil Uji Statistik Deskriptif Variabel Dummy

\begin{tabular}{|l|c|c|c|c|c|}
\hline \multirow{2}{*}{ Variabel } & \multirow{2}{*}{ Kategori } & \multicolumn{2}{c|}{ GAAP ETR } & \multicolumn{2}{c|}{ Current ETR } \\
\cline { 3 - 5 } & & Frekuensi & Persen & Frekuensi & Persen \\
\hline Kualitas & 0 = KAP non Big 4 & 515 & $49,9 \%$ & 515 & $50 \%$ \\
\cline { 2 - 5 } Audit & 1 KAP Big 4 & 518 & $50,1 \%$ & 515 & $50 \%$ \\
\hline
\end{tabular}

Sumber: Data sekunder diolah (2019)

\subsection{Panel Data Regression}

\subsubsection{Chow Test}

Uji Chow untuk GAAP ETR dan

Current ETR pada Tabel 5 masing-masing memperoleh angka probabilitas sebesar 0,00000 di bagian Cross-section Chi-square. Hasil ini berada $<0,05$, sehingga model FEM paling sesuai untuk dilakukan pengujian penelitian.
Tabel 5

Hasil Uji Chow

\begin{tabular}{|l|c|c|}
\hline \multirow{2}{*}{ Effect Test } & \multicolumn{2}{|c|}{ Prob. } \\
\cline { 2 - 3 } & GAAP ETR & Current ETR \\
\hline Cross-section F & 0,00000 & 0,00000 \\
\hline $\begin{array}{l}\text { Cross-section Chi- } \\
\text { square }\end{array}$ & 0,00000 & 0,00000 \\
\hline
\end{tabular}

Sumber: Data sekunder diolah (2019)

\subsubsection{Hausman Test}

Uji Hausman untuk GAAP ETR dan Current ETR pada Tabel 6 masing-masing memperoleh angka probabilitas sebesar 
0,0002 dan 0,0001 di bagian Cross-section random. Hasil ini berada $<0,05$, sehingga

model FEM paling sesuai untuk

dilakukan pengujian penelitian.

Tabel 6

Hasil Uji Hausman

\begin{tabular}{|l|c|c|}
\hline \multirow{2}{*}{ Effect Test } & \multicolumn{2}{|c|}{ Prob. } \\
\cline { 2 - 3 } & GAAP ETR & Current ETR \\
\hline $\begin{array}{l}\text { Cross-section } \\
\text { random }\end{array}$ & 0,0002 & 0,0001 \\
\hline
\end{tabular}

Sumber: Data sekunder diolah (2019)

\subsubsection{F Test}

Hasil uji F pada Tabel 7 memperoleh nilai signifikansi sebesar $0,00000(<0,05)$ untuk GAAP ETR dan Current ETR. Hal ini

Tabel 8

Hasil Uji t GAAP ETR

\begin{tabular}{|l|l|l|l|c|}
\hline Variabel & Koefisien & Sig. & Kesimpulan & Hipotesis \\
\hline Konstanta & 0,81287 & 0,0012 & & \\
\hline Ukuran Perusahaan & $-0,02012$ & 0,0178 & Sig. - & Tidak Terbukti \\
\hline Leverage & 0,00632 & 0,8560 & Insig. & Tidak Terbukti \\
\hline Intensitas Modal & 0,05181 & 0,1643 & Insig. & Tidak Terbukti \\
\hline Intensitas Persediaan & 0,08931 & 0,1565 & Insig. & Tidak Terbukti \\
\hline Tingkat Pengembalian Aset & $-0,40156$ & 0,0000 & Sig. - & Terbukti \\
\hline Komite Audit & $-0,00229$ & 0,6856 & Insig. & Tidak Terbukti \\
\hline Kepemilikan Institusional & 0,09596 & 0,0002 & Sig. + & Terbukti \\
\hline Komisaris Independen & $-0,00415$ & 0,8954 & Insig. & Tidak Terbukti \\
\hline Kualitas Audit & 0,01689 & 0,2317 & Insig. & Tidak Terbukti \\
\hline
\end{tabular}

Sumber: Data sekunder diolah (2019)

Tabel 9

Hasil Uji t Current ETR

\begin{tabular}{|l|c|c|c|c|}
\hline Variabel & Koefisien & Sig. & Kesimpulan & Hipotesis \\
\hline Konstanta & 0,68857 & 0,0053 & & \\
\hline Ukuran Perusahaan & $-0,01722$ & 0,0391 & Sig. - & Tidak Terbukti \\
\hline Leverage & 0,07450 & 0,0280 & Sig. + & Tidak Terbukti \\
\hline Intensitas Modal & 0,04792 & 0,1902 & Insig. & Tidak Terbukti \\
\hline Intensitas Persediaan & 0,06132 & 0,3232 & Insig. & Tidak Terbukti \\
\hline Tingkat Pengembalian Aset & $-0,29862$ & 0,0000 & Sig. - & Terbukti \\
\hline Komite Audit & 0,00463 & 0,4164 & Insig. & Tidak Terbukti \\
\hline Kepemilikan Institusional & 0,06986 & 0,0052 & Sig. + & Terbukti \\
\hline Komisaris Independen & $-0,03790$ & 0,2189 & Insig. & Tidak Terbukti \\
\hline Kualitas Audit & 0,01021 & 0,4577 & Insig. & Tidak Terbukti \\
\hline
\end{tabular}

Sumber: Data sekunder diolah (2019)

Pengujian ukuran perusahaan menunjukkan pengaruh signifikan negatif terhadap kedua variabel dependen (GAAP ETR dan Current ETR) dengan nilai signifikansi masing-masing adalah 0,0391 dan 0,0178 , sehingga $\mathrm{H}_{1}$ ditolak. Hasil ini sejalan dengan Irianto et al. (2017), Turyatini (2017), dan Zulaikha (2014) yang menandakan bahwa variabel independen terhadap variabel dependen memiliki pengaruh yang simultan.

Tabel 7

Hasil Uji F

\begin{tabular}{|l|c|c|}
\hline Variabel Dependen & Sig. & Kesimpulan \\
\hline GAAP ETR & 0,00000 & Signifikan \\
\hline Current ETR & 0,00000 & Signifikan \\
\hline
\end{tabular}

Sumber: Data sekunder diolah (2019)

\subsection{4 t Test}

Uji t berfungsi untuk menilai tingkat signifikansi variabel bebas terhadap variabel dependen dan membandingkan hasilnya dengan hipotesis yang telah dirumuskan sebelumnya. 
Pengujian leverage menunjukkan pengaruh signifikan positif terhadap GAAP ETR dan nilai signifikansi sebesar 0,0280, sehingga $\mathrm{H}_{2}$ ditolak. Hasil penelitian Dharma dan Ardiana (2016), Rani et al. (2018), dan Turyatini (2017) juga sesuai, dimana leverage berpengaruh signifikan positif terhadap ETR. Pendanaan yang didapat dari pinjaman telah dimanfaatkan oleh perusahaan untuk memperoleh penghasilan.

Pengujian leverage menunjukkan pengaruh tidak signifikan terhadap Current ETR dengan nilai signifikansi sebesar 0,8560, sehingga $\mathrm{H}_{2}$ ditolak. Hasil penelitian Harjito et al. (2017), Pratama (2017), serta Sonia dan Suparmun (2019) juga sesuai dimana leverage tidak berpengaruh signifikan terhadap ETR. Menurut Harjito et al. (2017), biaya bunga yang tinggi menyebabkan perusahaan untuk tidak melakukan pendanaan dari pinjaman hanya untuk meminimalisasi pajak yang dibayar.

Pengujian intensitas modal menunjukkan pengaruh tidak signifikan terhadap kedua variabel dependen (GAAP ETR dan Current ETR) dengan nilai signifikansi masing-masing ialah 0,1902 dan 0,1643 , sehingga $\mathrm{H}_{3}$ ditolak. Hasil ini sejalan dengan Prasetyo et al. (2018), Sonia dan Suparmun (2019), serta Yustrianthe dan Niandari (2018) dimana intensitas modal tidak berpengaruh signifikan terhadap ETR. Irianto et al. (2017) mengindikasikan bahwa aset tetap tidak memberikan dampak yang cukup terhadap kegiatan penghindaran pajak. Aset tetap perusahaan tidak digunakan untuk menghindar pajak, melainkan digunakan untuk menjalani operasional perusahaan (Dharma \& Ardiana, 2016).

Pengujian intensitas persediaan menunjukkan pengaruh tidak signifikan terhadap kedua variabel dependen (GAAP ETR dan Current ETR) dengan nilai signifikansi masing-masing adalah 0,3232 dan 0,1565 , sehingga $\mathrm{H}_{4}$ ditolak. Hasil ini sejalan dengan Sonia dan Suparmun (2019) dan Damayanti dan Gazali (2018) dimana intensitas persediaan tidak mempunyai pengaruh yang kuat terhadap pajak. Intensitas persediaan pada setiap perusahaan memiliki tingkat perputaran persediaan yang berbeda dari tahun ke tahun, tergantung permintaan pasar, kebijakan perusahaan, dan faktor-faktor lain (Damayanti \& Gazali, 2018).

Pengujian tingkat pengembalian aset menunjukkan pengaruh signifikan negatif terhadap kedua variabel dependen (GAAP ETR dan Current ETR) dengan nilai signifikansi masing-masing adalah 0,0000 dan 0,0000 , sehingga $\mathrm{H}_{5}$ terbukti. Hasil ini sejalan dengan Kraft (2014), Parisi (2016), dan Wiratmoko (2018). Menurut Sonia dan Suparmun (2019), perusahaan yang menghasilkan tingkat pengembalian aset yang semakin tinggi memiliki lebih banyak ruang dan sumber daya untuk melakukan perencanaan pajak untuk mengurangi beban pajak.

Pengujian komite audit menunjukkan pengaruh tidak signifikan terhadap kedua variabel dependen (GAAP ETR dan Current $E T R$ ) dengan nilai signifikansi masingmasing adalah 0,4164 dan 0,6856, sehingga $\mathrm{H}_{6}$ ditolak. Hasil ini sejalan dengan Astuti et al. (2018), Mais dan Patminingih (2017), dan Prasetyo et al. (2018). Hasil ini mengindikasi bahwa terdapat ketidakmampuan komite audit dalam meningkatkan pemantauan terhadap manajemen karena keterbatasan kekuasaan komite audit oleh dewan komisaris (Mais \& Patminingih, 2017).

Pengujian kepemilikan institusional menunjukkan pengaruh signifikan positif terhadap kedua variabel dependen (GAAP ETR dan Current ETR) dengan nilai signifikansi masing-masing adalah 0,0052 dan 0,0002 , sehingga $\mathrm{H}_{7}$ terbukti. Hasil ini sejalan dengan Mappadang et al. (2018), Marselawati et al. (2018), serta Sonia dan Suparmun (2019). Investor institusional tidak menyetujui pihak manajemen untuk melakukan penghindaran pajak yang hasilnya akan merugikan perusahaan di masa depan dan mereka berkomitmen dan patuh untuk mengikuti hukum pajak (Mappadang et al., 2018).

Pengujian komisaris independen menunjukkan pengaruh tidak signifikan terhadap kedua variabel dependen (GAAP 
ETR dan Current ETR) dengan nilai signifikansi masing-masing adalah 0,2189 dan 0,8954 , sehingga $\mathrm{H}_{8}$ ditolak. Hasil ini sejalan dengan Arismajayanti dan Jati (2017), Sonia dan Suparmun (2019), dan Turyatini (2017). Komisaris independen perusahaan belum efektif karena tidak menjalankan peran pengawasan terhadap manajemen yang benar dan kehadiran komisaris independen hanya bertindak sebagai pemenuhan persyaratan kepatuhan regulasi (Arismajayanti \& Jati, 2017).

Pengujian kualitas audit menunjukkan pengaruh tidak signifikan terhadap kedua variabel dependen (GAAP ETR dan Current ETR) dengan nilai signifikansi masing-masing adalah 0,4577 dan 0,2317 , sehingga $\mathrm{H}_{9}$ ditolak. Hasil ini sejalan dengan Marselawati et al. (2018), Prasetyo et al. (2018), serta Yustrianthe dan Niandari (2018). Kualitas audit yang di jalankan oleh KAP Big 4 memang lebih dipercaya karena memiliki reputasi dan integritas tinggi, tetapi jika perusahaan bisa memberikan keuntungan kepada KAP, KAP berkemungkinan melakukan kecurangan dalam artian hasil audit sesuai dengan peraturan yang berlaku demi meningkatkan kesejahteraan KAP (Prasetyo et al., 2018).

\subsubsection{Adjusted $R$ Square Test}

Tabel di bawah menunjukkan Adjusted R Square untuk GAAP ETR sebesar 0,68728. Hasil ini menandakan variabel independen mampu menjelaskan GAAP ETR sebesar $68,728 \%$, sedangkan $31,272 \%$ dijelaskan oleh variabel lain yang tidak terdapat pada penelitian. Adjusted $R$ Square untuk Current ETR sebesar 0,72686. Hasil ini menandakan variabel independen mampu menjelaskan Current ETR sebesar 72,686\%, sedangkan $27,314 \%$ dijelaskan oleh variabel lain yang tidak terdapat pada model penelitian.

Tabel 10

Hasil uji Adjusted R Square

\begin{tabular}{|l|c|c|}
\hline \multirow{2}{*}{ Effect Test } & \multicolumn{2}{|c|}{ Adjusted R Square } \\
\cline { 2 - 3 } & GAAP ETR & Current ETR \\
\hline Adjusted R-Square & 0,68728 & 0,72686 \\
\hline
\end{tabular}

Sumber: Data sekunder diolah (2019)

\section{KESIMPULAN}

\subsection{Kesimpulan}

Hasil pengujian menyimpulkan bahwa tingkat pengembalian aset dan ukuran perusahaan berpengaruh signifikan negatif, sedangkan kepemilikan institusional berpengaruh signifikan positif terhadap kedua variabel dependen, yaitu GAAP ETR dan Current ETR. Leverage berpengaruh signifikan positif terhadap GAAP ETR, tetapi tidak berpengaruh signifikan terhadap Current ETR. Variabel independen lainnya, yaitu kualitas audit, intensitas persediaan, komite audit, intensitas modal, dan komisaris independen tidak menunjukkan adanya pengaruh signifikan terhadap GAAP ETR dan Current ETR.

\subsection{Keterbatasan}

Keterbatasan pada penelitian yang diteliti antara lain:

1. Jangka periode penelitian hanya dibatasi selama 5 tahun, yakni 20142018.

2. Penelitian yang di dalami hanya tertuju pada daftar perusahaan di pasar modal BEI.

3. Variabel pada model penelitian yang di dalami masih minim.

\subsection{REKOMENDASI}

Rekomendasi untuk penelitian kedepannya, antara lain:

1. Disarankan kepada pengamat atau peneliti kedepannya untuk menambah sampel penelitian, dengan artian sampel penelitian diperbanyak (> 5 tahun).

2. Disarankan kepada peneliti untuk memperluas cakupan sampel penelitian, yaitu sampel penelitian tidak hanya diambil dari pasar modal di Indonesia.

3. Direkomendasi kepada peneliti ketika mendesain model penelitian berikutnya untuk menambah variabel yang dianggap mampu meningkatkan keakuratan penelitian, seperti koneksi politik (Wahab et al., 2017), 
kompensasi eksekutif (Widuri et al., 2019), dan lain-lain.

\section{DAFTAR PUSTAKA}

Arismajayanti, N. P. A., \& Jati, I. K. (2017). Influence of audit committee competence, audit committee independence, independent commissioner, and leverage on tax aggressiveness. Journal of Auditing, Finance, and Forensic Accounting, 5(2), 109-119.

Astuti, M. T., Titisari, H., \& Nurlaela, S. (2018). Characteristics influence of corporate governance and firm performance against tax avoidance (Empirical study on beverage company listed on the indonesia stock exchange year 2012 to 2015). The 2nd International Conference on Technology, Education, and Social Science 2018, 2, 83-92.

Bapepam-LK. (2012). Peraturan Nomor IX.I.5 tentang Pembentukan dan Pedoman Pelaksanaan Kerja Komite Audit. Jakarta: Ketua Badan Pengawas Pasar Modal dan Lembaga Keuangan.

Damayanti, T., \& Gazali, M. (2018). Pengaruh capital intensity ratio dan inventory intensity ratio terhadap effective tax rate. Seminar Nasional Cendekiawan Ke 4, 4(2), 1237-1242.

Delgado, F. J., Rodriguez, E. F., \& Arias, A. M. (2012). Size and other determinants of corporate effective tax rates in US listed companies. International Research Journal of Finance and Economics, (98), 160-165.

Dharma, I. M. S., \& Ardiana, P. A. (2016). Pengaruh leverage, intensitas aset tetap, ukuran perusahaan, dan koneksi politik terhadap tax avoidance. E-Jurnal Akuntansi Universitas Udayana, 15(1), 584-613.

Gupta, S., \& Newberry, K. (1997). Determinants of the variability in corporate effective tax rates: Evidence from longitudinal data. Journal of Accounting and Public Policy, 34(16), $1-34$.
Harjito, Y., Sari, C. N., \& Yulianto, Y. (2017). Tax aggressiveness seen from company characteristics and corporate social responsibility. Journal of Auditing, Finance, and Forensic Accounting, 5(2), 77-91.

Hsieh, Y. C. (2013). The heterogeneous relation between firm size and corporate effective tax rates: Evidence from listed companies in China. Journal of Interdisciplinary Mathematics, 16(4-5), 297-308.

Indriantoro, N., \& Supomo, B. (2014). Metodologi Penelitian Bisnis untuk Akuntansi dan Manajemen. Yogyakarta: BPFE.

Inua, O. . (2018). Determinants of corporate effective tax rates: Empirical evidence from listed manufacturing companies in Nigeria. Accounting and Taxation Review, 2(3), 49-61.

Irianto, B. S., Sudibyo, Y. A., \& Wafirli, A. (2017). The influence of profitability, leverage, firm size, and capital intensity towards tax avoidance. International Journal of Accounting and Taxation, 5(2), 33-41.

Jasrial, Puspitasari, S., \& Muktiyanto, A. (2018). Earnings management, effective tax rate (ETR), and book tax gap (BTG). Accounting and Finance Review Journal, 3(1), 33-43.

Khaoula, A., \& Ali, Z. M. (2012). The board of directors and the corporate tax planning: Empirical evidence from Tunisia. International Journal of Accounting and Financial Reporting, 2(2), 142-157.

Koh, Y., \& Lee, H. A. (2015). The effect of financial factors on firms financial and tax reporting decisions. Asian Review of Accounting, 23(2), 110-138.

Kraft, A. (2014). What really affects German firms effective tax rate? International Journal of Financial Research, 5(3), 119.

Kurniasih, L., Sulardi, \& Suranta, S. (2017). Earning managements, corporate governance, and tax avoidance: The case in Indonesia. Journal of Finance and 
Banking Review, 2(4), 28-35.

Mahulae, E. E., Pratomo, D., \& Nurbaiti, A. (2016). Pengaruh kepemilikan institusional, kepemilikan manajerial, dan komite audit terhadap tax avoidance. E-Proceeding of Management, 3(2), 1626-1633.

Mais, R. G., \& Patminingih, D. (2017). Effect of good corporate governance on tax avoidance of the company in listed of the indonesia stock exchange. Jurnal STEI Ekonomi, 26(2), 230-243.

Mappadang, A., Widyastuti, T., \& Wijaya, A. M. (2018). The effect of corporate governance mechanism on tax avoidance: Evidence from manufacturing industries listed in the indonesian stock exchange. The International Journal of Social Sciences and Humanities Invention, 5(10), 50035007.

Marselawati, D., Titisari, K. H., \& Masitoh, E. (2018). The effect of corporate governance on tax avoidance (Empirical study of the consumer goods industry companies listed on indonesia stock exchange period 2013-2016). The 2nd International Conference on Technology, Education, and Social Science 2018, 2(1), 123-132.

Maskanah, \& Islahuddin. (2019). The influence of leverage, density of fixed assets, and independent commissioners on effective companies tax rate in Indonesia. Journal of Accounting, Finance, and Auditing Studies, 5(2), 2437.

Masripah, Diyanty, V., \& Fitriasari, D. (2016). Controlling shareholder and tax avoidance: Family ownership and corporate governance. International Research Journal of Business Studies, 8(3), 167-180.

Minnick, K., \& Noga, T. (2010). Do corporate governance characteristics influence tax management? Journal of Corporate Finance, 16(5), 703-718.

Murni, Y., Sudarmaji, E., \& Sugihyanti, E. (2016). The role of institutional ownerships, board of independent commissioner, and leverage: Corporate tax avoidance in Indonesia. IOSR Journal of Business and Management, 18(11), 79-85.

Noor, R. M., Fadzillah, N. S. M., \& Mastuki, N. (2010a). Corporate tax planning: A study on corporate effective tax rates of Malaysian listed companies. International Journal of Trade, Economics and Finance, 1(2), 189-193.

Nugroho, W. C., \& Agustia, D. (2017). Tax avoidance, firm value, and corporate governance. AFEBI Accounting Review, 2(2), 15-29.

Ogbeide, S. O. (2017). Firm characteristics and tax aggressiveness of listed firms in Nigeria: Empirical evidence. International Journal of Academic Research in Public Policy and Governance, 4(1), 556-569.

Parisi, V. (2016). The determinants of Italy's corporate tax rates: An empirical investigation. Public and Municipal Finance, 5(4), 7-14.

Prasetyo, A., Masitoh, E., \& Wijayanti, A. (2018). The influence of good corporate governance, capital intensity ratio, and profitability to effective tax rate (Empirical study on manufacturing companies basic industry sectors and chemicals listed in indonesia stock exchange year 2011-2015). The 2nd International Conference on Technology, Education, and Social Science 2018, 2, 73-82.

Pratama, A. (2017). Company characteristics, corporate governance, and aggressive tax avoidance practice: A study of Indonesian companies. Review of Integrative Business and Economics Research, 6(4), 70-80.

Prima, B. (2019). Dilaporkan Melakukan Penghindaran Pajak, Bentoel Angkat Bicara. Retrieved from https://nasional.kontan.co.id/news/dilapo rkan-melakukan-penghindaran-pajakbentoel-angkat-bicara

Putri, S. E. (2016). Pengaruh ukuran perusahaan, return on asset (ROA), leverage, dan intensitas modal terhadap 
tarif pajak efektif. Jurnal Online Mahasiswa Fakultas Ekonomi, 3(1), 1506-1519.

Rahimipour, A. (2017). Investigation of the impact of women representation and participation on board of directors on tax avoidance in listed companies on the tehran stock exchange (TSE). Specialty Journal of Accounting and Economics, 3(2), 12-22.

Rani, S., Susetyo, D., \& Fuadah, L. L. (2018). The effects of the corporate's characteristics on tax avoidance moderated by earnings management (Indonesian evidence). Journal of Accounting, Finance and Auditing Studies, 4(3), 149-169.

Rego, S. O. (2003). Tax-avoidance activities of U.S. multinational corporations. Contemporary Accounting Research, 20(4), 805-833.

Richardson, G., \& Lanis, R. (2007). Determinants of the variability in corporate effective tax rates and tax reform: Evidence from Australia. Journal of Accounting and Public Policy, 26(6), 689-704.

Richardson, G., Taylor, G., \& Lanis, R. (2013). The impact of board of director oversight characteristics on corporate tax aggressiveness: An empirical analysis. Journal of Accounting and Public Policy, 32(3), 68-88.

Rodríguez, E. F., \& Arias, A. M. (2014). Do business characteristics determine an effective tax rate? Emerging Markets Finance \& Trade, 50(3), 214-228.

Salaudeen, Y. M., \& Akano, R. O. (2018). Non-linearity in determinants of corporate effective tax rate: Further evidence from Nigeria. International Journal of Economics and Financial Research, 4(3), 56-63.

Savitri, E., \& Andreas. (2017). Determinants of effective tax rate of the top 45 largest listed companies of Indonesia. International Journal of Management Excellence, 9(3), 1183-1188.

Sonia, S., \& Suparmun, H. (2019). Factors influencing tax avoidance. Advances in
Economics, Business, and Management Research, 73(5), 238-243.

Stickney, C. P., \& Mcgee, V. E. (1982). Effective corporate tax rates the effect of size, capital intensity, leverage, and other factors. Journal of Accounting and Public Policy, 1(1), 125-152.

Sugianto, D. (2019). Mengenal soal Penghindaran Pajak yang Dituduhkan ke Adaro. Retrieved from https://finance.detik.com/beritaekonomi-bisnis/d-4612708/mengenalsoal-penghindaran-pajak-yangdituduhkan-ke-adaro

Sugiyono. (2017). Metode Penelitian Kuantitatif, Kualitatif, dan $R \& D$. Bandung: Alfabeta.

Tandean, V. A., \& Winnie, W. (2016). The effect of good corporate governance on tax avoidance: An empirical study on manufacturing companies listed in IDX period 2010-2013. Asian Journal of Accounting Research, 1(1), 28-38.

Timotius, K. H. (2017). Pengantar Metodologi Penelitian: Pengantar Manajemen Pengetahuan untuk Perkembangan Pengetahuan. Yogyakarta: Andi.

Turyatini. (2017). The analysis of tax avoidance determinant on the property and real estate companies. Jurnal Dinamika Akuntansi, 9(2), 143-153.

Undang-Undang Republik Indonesia Nomor 36 Tahun 2008 Tentang Perubahan Keempat Atas Undang-Undang Nomor 7 Tahun 1983 Tentang Pajak Penghasilan.

Wahab, E. A. A., Ariff, A. M., Marzuki, M. M., \& Sanusi, M. Z. (2017). Political connections, corporate governance, and tax aggressiveness in Malaysia. Asian Review of Accounting, 1-52.

Waluyo. (2017). The effect of good corporate governance on tax avoidance: Empirical study of the Indonesian banking company. The Accounting Journal of Binaniaga, 02(02), 1-10.

Widuri, R., Wijaya, W., Effendi, J., \& Cikita, E. (2019). The effect of good corporate governance on tax avoidance of listed companies in indonesian stock exchange 
in 2015-2017. Journal of Economics and Business, 2(1), 120-126.

Wiratmoko, S. (2018). The effect of corporate governance, corporate social responsibility, and financial performance on tax avoidance. The Indonesian Accounting Review, 8(2), 245-257.

Yustrianthe, R. H., \& Niandari, N. (2018). Tax avoidance practice: Political connection, firm characteristics, and audit quality test at banking industry in Indonesia. International Journal of Business Management and Economic Research, 9(3), 1296-1303.

Zeng, T. (2014). Derivative financial instruments, tax aggressiveness, and firm market value. Journal of Financial
Economic Policy, 6(4), 376-390.

Zheng, T., Jiang, W., Zhao, P., Jiang, J., \& Wang, N. (2019). Will the audit committee affects tax aggressiveness? Proceedings of the Twelfth International Conference on Management Science and Engineering Management, 12, 13131326.

Zimmerman, J. L. (1983). Taxes and firm size. Journal of Accounting and Economics, 5, 119-149.

Zulaikha, D. A. (2014). Pengaruh size, leverage, profitability, capital intensity ratio, dan komisaris independen terhadap effective tax rate (ETR). Diponegoro Journal of Accounting, 3(2), 1-9. 